Research, part of a Special Feature on Practicing Panarchy: Assessing Legal Flexibility, Ecological Resilience, and Adaptive Governance in U.S. Regional Water Systems Experiencing Climate Change

\title{
Balancing stability and flexibility in adaptive governance: an analysis of tools available in U.S. environmental law
}

\author{
Robin Kundis Craig ${ }^{1,2}$, Ahjond S. Garmestani ${ }^{3}$, Craig R. Allen ${ }^{4,5,6}$, Craig Anthony (Tony) Arnold ${ }^{7,8}$, Hannah Birgé ${ }^{6}$, Daniel A. \\ $\underline{\text { DeCaro }}^{9}$, Alexander K. Fremier $^{10}$, Hannah Gosnell $^{11}$ and Edella Schlager ${ }^{12}$
}

\begin{abstract}
Adaptive governance must work "on the ground," that is, it must operate through structures and procedures that the people it governs perceive to be legitimate and fair, as well as incorporating processes and substantive goals that are effective in allowing social-ecological systems (SESs) to adapt to climate change and other impacts. To address the continuing and accelerating alterations that climate change is bringing to SESs, adaptive governance generally will require more flexibility than prior governance institutions have often allowed. However, to function as good governance, adaptive governance must pay real attention to the problem of how to balance this increased need for flexibility with continuing governance stability so that it can foster adaptation to change without being perceived or experienced as perpetually destabilizing, disruptive, and unfair. Flexibility and stability serve different purposes in governance, and a variety of tools exist to strike different balances between them while still preserving the governance institution's legitimacy among the people governed. After reviewing those purposes and the implications of climate change for environmental governance, we examine psychological insights into the structuring of adaptive governance and the variety of legal tools available to incorporate those insights into adaptive governance regimes. Because the substantive goals of governance systems will differ among specific systems, we do not purport to comment on what the normative or substantive goals of law should be. Instead, we conclude that attention to process and procedure (including participation), as well as increased use of substantive standards (instead of rules), may allow an increased level of substantive flexibility to operate with legitimacy and fairness, providing the requisite levels of psychological, social, and economic stability needed for communities to adapt successfully to the Anthropocene.
\end{abstract}

Key Words: adaptive governance; balance; due process; equity; fairness; legitimacy; nonequilibrium; procedure; resilience; rule; standard

\section{INTRODUCTION}

As the introductory and "role of law" (Cosens et al. 2017) articles in this special feature (Chaffin et al. 2017) have made clear, the goal of adaptive governance is to cope with change in socialecological systems (SESs). However, adaptive governance also needs to work "on the ground," i.e., it must not only effectively manage changing SESs but also operate as a legitimate and effective governance system that meets both the psychological needs of the individuals governed and the socioeconomic needs of the communities involved. Here, we focus on the structural and procedural characteristics that emergent adaptive governance systems will need in order to govern well. Specifically, because adaptive governance arises to cope with change, it must pay real attention to the problem of how to balance the need for increased flexibility with continuing governance stability so that it can foster adaptation to change without being perceived or experienced as perpetually destabilizing, disruptive, and unfair.

As is described in this special feature's introductory article, "governance" encompasses the means through which a community chooses its collective goals, makes decisions, and takes action to achieve the chosen goals. As other articles in this feature have noted, governance encompasses not only government, but also the relationship between government and society and less formal institutions. "Stability" in governance institutions refers to the persistence over time, in the same or similar form, of governance structures (e.g., the branches of government and their implementing bodies at all levels, the rule of law, nongovernmental governance institutions such as industry groups); of substantive rules, standards, and norms; and of procedural requirements and opportunities, including public and interest group participation. "Flexibility" refers to the degree of latitude possible within a given governance structure (e.g., swings from conservative to liberal perspectives); within its substantive rules, standards, and norms (e.g., discretion in interpretation, implementation, and application; exceptions and variances; amendments); and within its procedural requirements (e.g., the use of more or less formal procedures or abbreviated procedures) without fundamentally breaching or displacing the governance system as a whole (as, at the extreme, in a revolution). Importantly, however, structure, substance, and procedure are three distinct (if interrelated) aspects of governance systems, and the design for stability or flexibility within each aspect can differentially affect the legitimacy and effectiveness of the overall governance system. For example, no matter how attentive a system is to inclusive participation and procedural due process, it will not be perceived

${ }^{1}$ Wallace Stegner Center for Land, Resources, University of Utah S.J. Quinney College of Law, Salt Lake City, UT, USA, ${ }^{2}$ University of Utah Global Change and Sustainability Center, Salt Lake City, UT, USA, ${ }^{3}$ U.S. Environmental Protection Agency, Cincinnati, OH, USA, ${ }^{4}$ U.S. Geological Survey, ${ }^{5}$ Nebraska Cooperative Fish and Wildlife Research Unit, ${ }^{6}$ School of Natural Resources, University of Nebraska-Lincoln, Lincoln, NE, USA, ${ }^{7}$ Brandeis School of Law, Department of Urban \& Public Affairs, and Center for Land Use \& Environmental Responsibility, University of Louisville, Louisville, KY, USA, ${ }^{8}$ UCLA School of Law, Los Angeles, CA, USA, ${ }^{9}$ Social Decision Making and Sustainability Lab, Department of Urban and Public Affairs, Department of Psychological and Brain Sciences, University of Louisville, Louisville, KY, USA, ${ }^{10}$ School of the Environment, Washington State University, Pullman, WA, USA, ${ }^{11}$ College of Earth, Ocean and Atmospheric Sciences, Oregon State University, Corvallis, OR, USA, ${ }^{12}$ School of Government and Public Policy, University of Arizona, Tucson, AZ, USA 
as legitimate if the substantive rules discriminate against important subgroups within the governed community. Conversely, substantive rules that are initially sound may become unfairly outdated if governance structures do not allow for their periodic amendment, or they may come to be perceived as illegitimate if their application in practice is arbitrary.

The Anthropocene warrants a more comprehensive examination of the stability-flexibility balance in the governance of SESs and the tools available (Ruhl and Fischman 2010) to adjust and calibrate that balance to accommodate new and different ecological realities (Doremus 2010, Ruhl 2011, Camacho and Glicksman 2016). It is now recognized that not all aspects of governance systems need to be equally flexible or equally stable. In property law, for example, allowable forms of land ownership can be traced to William the Conqueror's imposition of a feudal system on England in 1066. In contrast, landlord-tenant relationships and real estate contracting have evolved to encompass contemporary norms of consumer protection, and 20th century introductions of zoning and land-use planning have achieved widespread acceptance as a means to address the particular problems of crowded cities (Rabin 1984, Sprankling and Coletta 2012). Thus, a range of approaches to balancing stability and flexibility can operate simultaneously to address different issues, particularly in light of other potentially confounding issues such as resource uncertainly and politics (Biber and Eagle 2015). Ecologists have long known that SESs are not static and that there is no "balance of nature" responsive to top-down, command-and-control governance (Holling 1973, Holling and Meffe 1996). However, governance entities have been reluctant to acknowledge this truth. This failure to adjust governance institutions to ecological realities is quickly becoming critical because global climate change is now accelerating ecological variability (Craig 2010a, Steffen et al. 2015), obliterating any illusion that SESs are systems in balance. As a result, at least some aspects of governance systems must become more flexible to accommodate the increasingly changing (and increasingly perceptibly changing) ecological systems on which human societies depend (Camacho 2009, 2011, Craig 2010a, Doremus 2010, Ruhl 2011, Flatt 2012, Zellmer 2012, Camacho and Glicksman 2016) because the persistence of prior rules and management approaches (stability) in this world of accelerating change is itself becoming a source of destabilization (Baumgartner and Jones 2015). In other words, as past perceptions of relative stationarity are rapidly eroded by forces such as climate change and globalization, old governance mechanisms that emphasize stabilization are no longer tenable and are likely to exacerbate destabilization through inadvertent feedbacks. As a result, we require governance mechanisms that strategically maintain stability while flexibly accommodating, rather than rigidly repressing, unknown variability sure to arise on a rapidly changing planet.

Here, we examine psychological and sociological insights and the legal tools available to help achieve situation-appropriate calibrations of stability and flexibility in the governance systems that emerge to deal with a changing world. Although, by definition, there will never be a single formula for successful adaptive governance, adaptive governance systems can employ a variety of tools that will provide increased capacity to flexibly respond to social-ecological changes while maintaining sufficient stability to be deemed legitimate governance supportive of productive and viable communities. It is not our aim to proscribe specific substantive and normative goals for the governance of the Anthropocene, recognizing that specific goals will necessarily have to differ by location and adaptive situation (Zellmer and Gunderson 2009). Instead, we conclude that attention to process and procedure (including public and interest group participation), as well as increased use of substantive standards instead of rules, may allow an increased level of substantive flexibility to operate with legitimacy and fairness, providing the requisite levels of psychological, social, and economic stability needed for communities to adapt successfully to the Anthropocene.

\section{TRADE-OFFS ASSOCIATED WITH STABILITY AND FLEXIBILITY IN GOVERNANCE: THE NEED FOR A WORKABLE BALANCE}

\section{Virtues of stability in governance}

Stability is most important in the structural aspect of governance; recurring revolutions or military coups are the quintessential definition of destructive and destabilizing governance. Nevertheless, substantive and procedural stability are also important. Static laws, policies, and social norms, coupled with adequate process and transparency, provide predictability, enhance compliance and enforcement, provide a foundation of security, and encourage investment in productive enterprises (Levi-Faur 2012).

The sources of stability in governance arrangements are many and interconnected. Shared understandings among actors regarding appropriate behavior in different settings support predictability because actors develop stable expectations in relation to one another. For instance, in some river basins in New Mexico, USA, the State Engineer manages to avoid putting senior water rights holders in the position of having to cut off completely junior water rights holders, rather than strictly following the administration of priority water rights (Hall 2002). Such a norm allows more irrigators access to water for longer periods of time.

In addition to shared norms, predictability is supported by shared rules about what actions are allowed or forbidden, information that must be developed and communicated with others, and penalties for violating rules. For example, property rights systems define who holds what types of authority in relation to whom regarding resources. Holding property rights in a resource often allows actors a voice in how the resource is to be governed. For instance, water rights holders in Colorado, USA, are allowed to participate in water court proceedings, whereas actors without water rights face high barriers to entry.

Slowly changing configurations of norms, rules, and property rights allow people and organizations to engage in collective endeavors that generate benefits over long periods of time, benefits that no single actor alone could achieve. The stability created by governance arrangements allows people and organizations to learn about one another and the resources that they jointly manage and share, to plan for future contingencies such as drought or flooding, to invest in long-term activities, and to experiment with different forms of productive enterprises. Some level of stability is required for these activities to emerge. For example, the very complex "Law of the River" for the Colorado River, USA has provided the necessary stability in 
defining rights to water in the river to allow for experiments in adaptive management in Glen Canyon, USA and creative water storage solutions with Mexico.

\section{Danger of rigidity}

Nevertheless, too much stability, and the resulting predictability and consistency, comes with a price: rigidity. Rigidity defines governance systems that persist with the same activities and routines even though those actions are not well suited for the setting, especially when there are alternative governance arrangements that would likely enable greater benefits for communities and societies. This inability to adapt is often termed a rigidity trap (e.g., Carpenter and Brock 2008).

Rigidity exhibits a variety of forms. One form is the inability of a governance institution (such as a legislature or a court) to recognize and act on changing community and societal values. For example, courts and legislatures implementing the western prior appropriation doctrine for water rights have been reluctant to prioritize in-stream uses of water, be it for protecting aquatic species and habitat, improving water quality, or permitting recreational uses, despite western society's increasing valuation of these aquatic amenities. Another form of rigidity is the inability to recognize or act on threats to ecosystems' productivity such as land-use practices that fragment a landscape or water diversions from streams and rivers that threaten to decouple rivers from flood plains. Too much rigidity in governance systems can thus clearly interfere with good governance. Rigidity in federal administrative law, for example, thwarts increased efforts by federal agencies to engage in adaptive management (Ruhl and Fischman 2010).

Growing disjunction between governance arrangements, the requirements for ecosystems to persist in desirable states, and the values of different actors and communities threaten the viability of the governance arrangements by provoking conflict, heightening uncertainty, and undermining collective action. In time, systems trapped in rigidity almost inevitably confront some crisis in resource availability or management. These crises can both escalate the level of conflict within the SES and lead to new and, hopefully, more adaptive, governance arrangements (Chaffin et al 2014a).

\section{Virtues of flexibility in governance}

Governance systems require at least a modicum of flexibility because social systems are complex and adaptive (Holling 2001, Levi-Faur 2012). Thus, as is true in all governance structures, for adaptive governance, "flexibility is a prerequisite for accommodating changes in the environment of the organization and adapting public services to changing demand patterns" (LeviFaur 2012:197).

As Cosens et al. (2017) suggest, flexibility in governance is what allows societies to adjust governance patterns to reflect new social norms, that is, to adapt. However, it must be recognized that adaptation is not always smooth because it often upsets entrenched interests. For example, the 20th century American Civil Rights movement, which elevated the political statuses of minorities and women, came with violence and struggle, underscoring the potentially destabilizing effects of both too much rigidity in governance systems (e.g., the long-term denial of rights to minorities and women) and the exercise of flexibility in the insistence on enfranchisement. Similarly, the emergence of potential new governance systems in the Klamath River basin (Chaffin et al. 2014a) only came after years of polarizing litigation and a threat of violence.

\section{Danger of arbitrariness}

The primary public policy danger of too much flexibility in governance is arbitrariness. Important public values such as equal treatment, due process, and procedural fairness depend on stable governance institutions and consistent administration (Levi-Faur 2012, Cosens and Williams 2012, Cosens 2013). As such, governance systems often try to eliminate at least the worst forms of arbitrariness. For example, in administrative law, an agency's consistency in interpreting and applying the law can be a critical consideration by the reviewing court, helping to minimize the randomness in treatment of regulated entities that might otherwise emerge among multiple agency offices and a plethora of agency staff (Dotan 2005). Consistency reduces both transaction costs within institutional processes and uncertainty and anxiety among the governed, as well as promotes basic fairness (Levi-Faur 2012, Cosens and Williams 2012, Cosens 2013).

\section{Ongoing search for balance: example of the U.S. Constitution}

The importance of avoiding arbitrary governance (i.e., of constraining governance flexibility) is obvious in both the structure created by and the substance and procedures contained within the U.S. Constitution. Structurally, one of the overall goals of the drafters of the Constitution was to constrain the government's ability to devolve into monarchy or dictatorship. As such, separation of powers is an important structural principle of U.S. governance. Substantively, however, the Constitution also limits the ability of government to treat its citizens arbitrarily. Article I, for example, constrains the authority of Congress, giving it only enumerated powers $(\S 8)$ and explicitly prohibiting Congress from engaging in certain kinds of arbitrary behavior with regard to American citizens, e.g., limiting the suspension of habeas corpus to times of rebellion and invasion, and expressly forbidding bills of attainder and ex post facto laws that could upset settled expectation (§9).

The importance of avoiding arbitrariness, however, is most obvious in the Constitution's provisions that constrain how governments can interact with citizens, found primarily in the Bill of Rights and the post-Civil War Civil Rights Amendments. These amendments, moreover, demonstrate the important role of procedure in balancing stability and freedom from arbitrariness with flexibility. In addition to preserving basic freedoms such as freedom of speech and of religion (Amendment 1), the constitutional amendments also restrict the government (generally both federal and state governments) from arbitrarily interfering with citizens' lives. These constraints on arbitrary action include the often-litigated Fourth Amendment's insistence that there be no searches and seizures without a warrant based on probable cause, and the Fifth and Fourteenth Amendments' guarantees that no person will "be deprived of life, liberty, or property, without due process of law; nor shall private property be taken for public use, without just compensation." Notably, however, procedures add flexibility to these constraints: citizens can almost always consent to any government intrusion that they find appropriate; police officers can obtain warrants in the case 
of legitimate law enforcement; governments can deprive citizens of life, liberty, and property so long as constitutionally adequate procedures are followed and, in the case of property, compensation is paid. Like all workable governance systems, therefore, even the U.S. Constitution does not impose rigid inflexibility on its constituents. Instead, it creates a stable structure and set of rules that simultaneously provide for incursions. The U.S. Constitution thus suggests that, at some deeper level, flexibility is a component of, rather than an alternative to, stable governance regimes (Bednar 2008).

\section{THE DRIVER OF GOVERNANCE CHANGE IN THE ANTHROPOCENE: CLIMATE CHANGE AND STABILITY AND FLEXIBILITY IN ECOSYSTEMS}

Management of SESs requires governance systems that acknowledge the fundamental reality of those systems, which is change. Although change is fundamental to all complex systems, climate change is accelerating the pace, magnifying the scale, and increasing the uncertainty of that change, warranting new governance responses such as adaptive governance (Camacho 2009, 2011, Craig 2010a, Doremus 2010, Ruhl 2011, Flatt 2012, Zellmer 2012, Camacho and Glicksman 2016). We next review these ecological realities and their implications for governance.

\section{Recognition of continuous change in ecosystems}

For many centuries, the equilibrium view of natural systems as steady-state systems dominated human thinking (Botkin 1992). This view assumed that thermodynamic laws govern ecological systems and that fluctuations away from a stable center were random noise, were undesirable, and were not essential system functioning (Sullivan 1996). However, ecologists have come to appreciate ecological variability as an essential component of ecological functioning. Indeed, ecosystems do not come to rest at an equilibrium in the absence of disturbance. They are instead both highly variable and adaptive in that they continually change in response to conditions to improve their odds of survival and success (Mitchell 2009).

The understanding of ecosystem management is similarly evolving. Natural resource managers no longer consider nonlinear, threshold responses to management actions as aberrations from the expected outcome. In the late 20th century, equilibrium views of ecosystems were replaced with an understanding that ecosystems display linear and nonlinear responses, tipping points, multiple alternative states, and crossscale interactions (Gunderson and Holling 2002, Walker and Salt 2006, Peters 2015). An acknowledgment that scale is essential to disentangling complexity was also emerging in the literature (Bosserman 1983, Holling 1992, Levin 1992). Both intra- and cross-scale dynamics are important (Peterson et al. 1998) and affect the production of ecosystem services and emergent properties of systems such as resilience. Within a scale, the dynamics of collapse and renewal have been described as adaptive cycles, and the hierarchical set of nested adaptive cycles that characterize a system have been described as a panarchy (Gunderson and Holling 2002, Allen et al. 2014). In a panarchy, the collective intra- and cross-scale interactions give rise to complex behaviors (Holling et al. 2002, Allen et al. 2014). Although complex systems are unpredictable in detail, they are also self-organizing and resilient. Self-organizing systems comprise an array of interacting components with no central control (Mitchell 2009). Their collective activity gives rise to increasing complexity as their diversity of components and scales increases. They are also adaptive, learning and evolving in response to changing conditions to improve survival odds (Mitchell 2009). In a nutshell, ecosystems are profoundly complex and do not respond consistently over the long term to top-down management.

As human populations continue to expand, so does the demand for ecosystem services. When translated into environmental and natural resources governance, these demands often result in management that maximizes the current output of specific ecosystem services. However, the long-term societal reliance on productive ecosystems requires an approach that fosters resilience of desirable system states (Walker and Salt 2006). The temptation to manage for the maximized output of a single product (e.g., timber or cod) without acknowledging potential future thresholds or the possibility of a nonlinear response to human action undermines the entire system, as humans have observed repeatedly (Scheffer et al. 2001).

\section{Climate change complications}

Climate change is currently a major destabilizing force in SESs. In complex systems, intrinsic processes and structures are both the effect of self-organization and perpetuate self-organization. Emergent from this set of feedbacks in ecosystems are the services on which humanity depends (Birgé et al. 2014). Climate change is rapidly altering ecological feedbacks, threatening to undermine the ecological resilience of SESs (Benson and Craig 2014). When a system's defining processes or structures are undermined beyond some threshold, the entire system may lose its integrity and enter an alternative state (Scheffer et al. 2001). Climate change can induce these relatively fast shifts, setting in motion complex and often unpredictable ecological regime shifts, which may in turn destabilize current government systems and economic and political arrangements as the rate of ecosystem services generation on which societies depend falls sharply or even halts.

For example, climate change is rapidly altering global temperature and precipitation patterns and ocean chemistry (Milly et al. 2008, IPCC 2014). One result of these effects is mass migrations of species (Ruhl 2008), creating new species assemblages and food webs with unpredictable endpoints. Some of these range expansions, such as that of the pine beetle in the U.S. Mountain West and Canada, are visibly destructive to human interests (Carroll 2006). Other ecosystems such as the Arctic tundra are shifting across ecological thresholds (Allen et al. 2009). Still others such as coral reefs may simply disappear (Craig 2015). Systems that have been optimized for specific services, such as development of rivers for hydropower (Cosens and Fremier 2014) or irrigation (Birgé et al. 2014), may have less latitude for absorption of disturbance and may be more vulnerable to shifts to less desirable states as climate change proceeds.

Climate change thus exacerbates the ecological reality of continuous change in both magnitude and pace. Moreover, "[b] ecause of 'committed' warming - climate change that will occur regardless of the world's success in implementing mitigation measures, a result of the already accumulated greenhouse gases ('GHGs') in the atmosphere - what happens to social-ecological systems over the next decades, and most likely over the next few centuries, will largely be beyond human control" (Craig 
2010a:14). To an increasing extent, the past is no longer a reliable predictor of potential ecological management issues.

\section{Implications for governance}

Although ecologists have accepted that SESs operate in continuous states of change, many environmental and natural resource governance systems have not yet accommodated even the most benign expectations of change, let alone the potentially widespread destabilization that climate change is causing. For example, with a few notable exceptions (e.g., local land-use law), much U.S. environmental and natural resources law remains grounded in a preservationist paradigm, emphasizing maintenance of and restoration to baseline historical conditions (Craig 2010a). While such governance regimes give the illusion of stability, they assume a predictability and reversibility of ecological states that modern ecological studies and resilience theory flatly contradict (Craig 2010a). In the American West, for example, much water planning still largely relies on historical precipitation patterns and hydrographs for guidance, effectively assuming stationarity in the resource. However, as Milly et al. (2008:573) argue in this context, "stationarity is dead." It can no longer be assumed that "natural systems fluctuate within an unchanging envelop of variability" (Milly et al. 2008:573). Similarly, the U.S. Endangered Species Act seeks to preserve and recover species within their historic ranges, producing an uncomfortable fit with species migrations in the Anthropocene (Ruhl 2008).

There is also increasing recognition that the underlying dynamics driving social-ecological change are transforming because of climate change, producing a level of uncertainty that demands response. Natural systems, under the added pressure of a changing climate, will vary in ways that are difficult to anticipate. Thus, readjusting the stability-flexibility trade-offs in environmental governance is critical, both to recognize and respond better to dynamic SESs and also to recognize and respond better to uncertainty. The challenge society faces as the planet it relies on changes is that failure to adapt our governance systems by increasing their flexibility will lead to the collapse of SESs, yet failure to balance stability with increased flexibility could lead to the same result in economic and political systems (Victor 2012, Cosens and Williams 2012, Porter 2015).

Theorists have advocated a variety of approaches to correct this governance nonsequitur, but they also place different emphases on the need for more flexibility vs. the need to preserve governance stability (Doremus 2010, Ruhl 2011, Camacho and Glicksman 2016). Some researchers, for example, focus on the immediate need to increase governance flexibility and advocate that new theoretical frameworks and tools be incorporated into environmental and natural resources law, from principled flexibility (Craig 2010a) and resilience thinking (Cosens 2010, 2012, 2013, Craig and Benson 2013, Benson and Craig 2014) to adaptive management (Ruhl and Fischman 2010, Craig and Ruhl 2014) and the promotion of adaptive governance (Chaffin et al. 2014b, Green et al. 2015, Camacho and Glicksman 2016). Other scholars focus on how to maintain stability as environmental governance is improved for the Anthropocene such as by advocating for incremental adjustment (Cosens and Williams 2012) or by advocating that greater attention be paid to legitimacy when implementing adaptive measures (Cosens 2013) and other modifications (Ruhl 2008, Cosens and Williams 2012, Flatt 2012, Garmestani and Allen 2014).

Regardless of the approach, however, the adoption of these mechanisms has been limited. Hence, it is worth examining the range of psychological and theoretical insights regarding, and legal tools available to adjust, the balance of flexibility and stability in governance for a changing world.

\section{PSYCHOLOGICAL INSIGHTS REGARDING THE BALANCING OF STABILITY AND FLEXIBILIY IN ADAPTIVE GOVERNANCE}

As any politician knows, the psychological perceptions of the persons being governed matter regarding how a governance or legal system actually functions. Environmental psychology is rife with studies demonstrating major psychological barriers to legal innovation (Castro 2012), climate change policy (Cornforth 2009), and adaptive environmental governance (Swim et al. 2009, Moser and Ekstrom 2010). It is imperative that legal scholars understand certain fundamental psychological principles of stability, adaptation, and policy acceptance to anticipate potential barriers to adaptive governance and address them in legal design. Many factors affect social acceptance and feasibility of adaptive environmental governance (DeCaro et al. 2017). We next describe the role of trust, legitimacy, and fundamental needs in striking a balance between stability and flexibility in adaptive governance. These principles give insight into potential design features of adaptive legal frameworks that may help society navigate difficult transitions in response to climate change.

One of government's first tasks is to establish legal systems that help societal stakeholders develop trust in one another, government itself, and a secure future so that stakeholders can make and honor long-term agreements and work together to solve complex social-ecological dilemmas such as adaptation to climate change (Ostrom 1998, Parks et al. 2013). Hence, legal systems facilitate the stability necessary for societal cooperation (Hardin 1968). Contemporary environmental law tends to create this stability through "stationarity," i.e., policies and procedures that largely resist change (Craig 2010a, Green et al. 2015). Hence, stability is commonly equated with lack of change. Government officials and members of the general public also generally prefer stationarity, resisting legal innovation (e.g., Castro and Mouro 2011, Gifford and Comeau 2011), especially when it would alter existing power relationships, the economy, or lifestyles (DeCaro et al. 2017). This poses a significant challenge for legal scholars of adaptive governance. How can legal frameworks transition toward adaptive governance without completely alienating the societal stakeholders who depend on stable legal systems for security?

We propose that the answer lies in "good governance," i.e., elements of governmental procedures such as transparency, accountability, inclusiveness, and fairness (Chaffin et al. 2014a) that build trust and establish governmental legitimacy (Cosens 2013). It is important for governance in the Anthropocene to be perceived as legitimate and trustworthy, particularly when increased management flexibility is the goal (Cosens 2013), because these sentiments promote policy acceptance and help stakeholders tolerate uncertainty (Frey et al. 2004, Tyler 2006, DeCaro et al. 2017). Legitimacy and trust are vital substitutes for personal control and certainty in contemporary society (Tyler 
2006). People cede authority to legitimate leaders, organizations, and institutions, and look to them for guidance during times of crisis (Burger 1989, Tyler 2006). Legitimacy in governance builds trust (e.g., Tyler and Degoey 1995), helping to maintain societal order and create a sense of security, which aids in cooperation (Ostrom 1998, 2010), even while major elements of the law or environmental governance systems undergo significant change (e.g., Lafon et al. 2004, Leach and Sabatier 2005, McComas et al. 2011). Thus, rather than design for stationarity, legal systems can design for security.

Esty (2006) and Cosens (2013) have identified five overlapping sources of legitimacy for adaptive governance: (1) results-based legitimacy, derived from the fact that decisions are based on objective expertise and the results can be determined to be good; (2) order-based legitimacy, based on the fact that rules are clear, stable, and publicly available; (3) systemic legitimacy, based on the existence of checks and balances among institutions; (4) deliberative legitimacy, based on the inclusion of a public dialogue in the process of decision making; and (5) procedural legitimacy, derived from an open and transparent process of decision making and an explanation for the choices made. These aspects of good governance increase perceptions of legitimacy (Tyler 1990, 1998) and promote trust by supporting fundamental psychological needs for procedural justice (fair decision-making procedures; Tyler and Degoey 1995, Tyler 2006), security (orderliness and predictability; DeCaro et al. 2015), and selfdetermination (being able to pursue important societal goals in ways that align with one's core values; Ryan and Deci 2006, Moller et al. 2006). Court decisions (Gibson et al. 1998), law enforcement and environmental regulation (Tyler 1998, Ostrom 2010), environmental policy innovation (Attari et al. 2009, Lavergne et al. 2010), and government agency activities (e.g., Lafon et al. 2004, Turner et al. 2014) have been shown to benefit from these legitimacy-enhancing provisions, improving acceptance, compliance, and cooperation (Frey et al. 2004, DeCaro and Stokes 2008, 2013).

In the next two sections, we discuss the characteristics of governance systems and aspects of substantive law that may increase the likelihood of successfully balancing stability and flexibility. Many of these legal mechanisms incorporate the elements of good governance and legitimacy outlined above. For example, planned windows of opportunity for amendment, review, and public input on government agency activity (Craig and Ruhl 2014), which permit change at predetermined times and ensure governmental transparency and accountability, not only enhance predictability (orderliness) during change, but also increase legitimacy by incorporating provisions for fair decision making, appeal, and public participation, demonstrating elements of order-based, deliberative, and procedural legitimacy. Regulatory floors and ceilings grant additional decision-making authority to governance units, promoting their selfdetermination, but also constrain this discretion with standards that uphold rigorous scientific problem solving and require evidence-based decision making (results-based legitimacy; Garmestani and Benson 2013). Thus, even if ecosystems and governance systems undergo significant change because of major stressors such as climate change, environmental stakeholders may derive a sense of security in the procedures used to make important decisions about environmental governance and develop trust in governance authorities
(Lawrence et al. 1997), helping to ease difficult transitions and encourage better cooperation (Cosens 2013, DeCaro et al. 2017).

There are no panaceas for complex social-ecological dilemmas (Ostrom 2007). For example, there is growing distrust of formal governments and their institutions in contemporary U.S. society because of historical mismanagement, including participatory and environmental justice components, which are essential to perceived legitimacy (Arnstein 1969, Bullard and Johnson 2000, National Civic League 2013). However, with sufficient precaution (Reed 2008), and genuine commitment to good governance (DeCaro and Stokes 2008, 2013), it may be possible to improve legitimacy to support adaptive environmental governance (Cosens 2013, DeCaro et al. 2017).

Furthermore, factors other than legitimacy affect tolerance of change (DeCaro et al. 2017) and the human capacity for adaptation (Armitage 2007). For example, the individual and collective phenomenon of framing, i.e., perceiving the world through mental frameworks or schema that represent meaning, shapes the legal and governance regimes. Arnold (2014) has identified at least sixteen different frames of watersheds that are imbedded in U.S. law (e.g., watershed as water supply, watershed as drainage sink for waste, watershed as aquatic habitat). When individuals and groups persist in seeing a problem through a particular frame, the governance institutions that arise from and support this frame become relatively stable. However, humans, both individually and collectively, have the capacity to engage in reframing, which is seeing the world through a different mental framework or even shifting the dominant frame by which they act. The phenomenon of reframing contributes to the adaptive capacity of governance institutions, as well as the multiplicity of applicable legal regimes, thus creating flexibility (Arnold 2014). Additional approaches to balance stability and flexibility better that may enhance humankind's ability to cope with rapid and often unexpected change are discussed next in detail.

\section{DESIGNING GOVERNANCE STRUCTURES TO BALANCE STABILITY AND FLEXIBILITY}

To be effective and legitimate, adaptive governance systems must successfully balance stability and flexibility at the system level. Thus, the structure and design of governance, i.e., the division of authorities, definitions of those authorities, and requirements governing the interaction of authorities with the populations subject to them, is a key consideration in successfully balancing flexibility and stability in adaptive governance and other new governance systems that emerge to cope with the Anthropocene. Political scientists and policy scholars have paid careful attention to designing robust governance systems (Ostrom 1990, Filippov et al. 2004, Bednar 2008). The basic premise is that collective action rarely emerges spontaneously. Rather, collective action is a function of governance systems that provide stability and predictability while simultaneously allowing for change. We next examine tools for balancing stability and flexibility in governance at the system level, examining the characteristics that will help to make emerging adaptive governance structures successful.

\section{Characteristics of governance systems that successfully balance} stability and flexibility

Governance systems that exhibit the following general characteristics are more likely to be robust to a variety of ecological, economic, political, and social disturbances (Bednar 
2008). In other words, these characteristics have the potential to provide predictability while concurrently allowing for flexibility.

\section{Shared decision making}

Most U.S. environmental governance systems consist of multiple venues in which actors come together to make shared decisions. For instance, the governing arrangements for the New York City watersheds that protect the quality of drinking water for the city's millions of residents and visitors are administered by several venues. One develops and implements different programs among the towns and villages in the watersheds (New York Department of State 1997, Hanlon 2015), another monitors the agreement's implementation (New York Department of State 1997), and the New York City Department of Environmental Protection administers the watershed rules and regulations.

These and other venues support stability in different ways. Diverse interests and values are represented among the venues. Allowing a diversity of values to be represented in different decision-making venues permits the governance system to be responsive to the interests residing in the watersheds, which also enhances its legitimacy. Multiple venues may also act as a check on one another, calling out arbitrary actions. For example, if New York City fails to fund watershed programs or enter into program contracts, parties to the agreement may trigger a review of the city's water supply permit by the state's Department of Environmental Conservation, who may in turn restrict the permit. Accountability mechanisms, by encouraging parties to fulfill their commitments, support continued collective action to achieve environmental goals.

However, such complex environmental governing arrangements are also capable of supporting flexibility. Multiple independent venues may innovate actions and programs in some obvious and not so obvious ways. Decision-making bodies can develop new programs or revise and change existing programs and rules. Different programs and policies mean opportunities for learning and experimentation. In addition, multiple decision venues means that some actions, which may be viewed as arbitrary, may go unchecked, allowing for experimentation outside of the boundaries of the agreement (Bednar 2008). Somewhat paradoxically, rule-bending behavior can be important for keeping governing arrangements resilient (Garrick et al. 2016).

\section{Popular accountability}

The effectiveness of environmental governance is enhanced by incorporating different forms of popular accountability (Bednar 2008). Citizens, resource users, and interest groups all have roles to play in supporting stability and flexibility. Popular accountability mechanisms take a variety of forms, from elections for representatives and decision-making venues to participation on advisory bodies and popular protests. Each of these forms may be used to support stability. For instance, advisory committees can insist that officials and administrators implement programs and rules in a timely fashion. Moreover, each of these forms may be used to encourage flexibility, electing representatives with values and goals different from their predecessors.

\section{Transparency}

Transparency requires the creation of an information-rich environment. Craig (2010a) emphasizes this point by arguing that to respond more effectively to changing ecosystems, environmental governance arrangements should study everything all the time. Although, in practice, it is not possible to study everything all of the time, the point is well taken. Monitoring and evaluating ecosystems as well as the programs, rules and regulations, and activities of participants, followed by making the information easily accessible, supports stability and flexibility. Problem solving, whether it entails responding to a climate disturbance or an effort to shirk a commitment, requires multiple monitoring and information-gathering processes (Baumgartner and Jones 2015).

\section{Conflict resolution}

Disagreements happen, but not all disagreements rise to the level of requiring attention by the courts. The abovementioned characteristics may contribute to the resolution of conflicts. Decision-making venues allow representatives to work through differences as they make collective decisions. In addition, environmental governing arrangements are often designed to anticipate conflict and provide mechanisms for resolution. Indeed, a number of interstate river compacts provide for mediation and arbitration among member states (Schlager and Heikkila 2009). The New York City watersheds governance arrangements include a council that is tasked with hearing disputes and disagreements (New York Department of State 1997).

\section{Working together}

These four features of environmental governance arrangements are key in mediating the balance between stability and flexibility. Working in concert, they support robust governance that provides a level of predictability that encourages participation and investment while also providing opportunities for actors to adjust to changing social-ecological circumstances. They do this by managing the diversity of interests and values and paying attention and responding to changing ecosystems. It is a constant balancing act between stability and flexibility, but the more effective arrangements manage that balance well enough to accomplish some desired goals (Schlager and Blomquist 2008).

\section{Creating a stable governance structure that can accommodate change}

National governance stability can be broadly assessed by the length of time that the basic structure of government has remained unchanged. The United States' federal constitutional republic and commitment to federalism (the division of governmental authority between a national government and state, territorial, and tribal governments that are both subordinate and independent) has survived for more than two centuries, despite a civil war. Although it may sound paradoxical, this stable governmental structure incorporates sufficient structural flexibility to accommodate and incorporate societal change, so far avoiding the need for pervasive structural overhaul or revolution. Again, at the deepest structural level, allowing flexibility is an element of long-term stability in governance because it allows the avoidance of undesirable feedbacks and thus bolsters the overall resilience of the governance system.

\section{Formal allowance of amendment}

Change can be accommodated within a stable governance structure if the structure provides for its own formal amendment or alteration. The U.S. Constitution, for example, contains a 
formal amendment procedure (Article V) and has been amended 27 times. Most state constitutions similarly allow for their own amendment. Thus, the "safety valve" of an amendment process can avoid the self-destructive pattern of increasing rigidity in the legal structure (although amendments themselves can potentially contribute to this rigidity). For example, the United States and Canada are currently renegotiating the Columbia River Treaty, pursuant to the Treaty's own renegotiation provisions, allowing for the modernization of its environmental considerations (Cosens and Fremier 2014). In contrast, a lack of provision for amendment can often lead to long-term problems. For example, states created many of the interstate compacts that allocate the waters of interstate rivers in the late 19th and early 20th centuries and failed to include amendment procedures in many of them (Schlager and Heikkila 2009), creating rigidity trap problems in water management for the 21 st century (e.g., Birgé et al. 2014).

\section{Recurring opportunity to replace the implementing persons}

Another way to accommodate change within stable governance structures is to have those structures mandate that, on a predictable and regular basis, the composition of the people who compose the governance unit can be changed, i.e., through elections or government appointment processes. Regular opportunities to switch out government actors helps to ensure that outdated regimes cannot remain in place forever and provides a structural safety valve that can accommodate desires for change that might otherwise lead to a complete replacement (violent or otherwise) of the existing regime. Elections, in particular, both provide a mechanism for popular accountability and contribute to the psychological legitimacy of a governance system.

\section{DESIGNING ENVIRONMENTAL AND NATURAL RESOURCES LAW TO CALIBRATE THE STABILITY- FLEXIBILITY BALANCE}

Law is a central facet of governance (Garmestani et al. 2013), including adaptive governance. For example, Camacho and Glicksman (2016) have explored the role of legal adaptive capacity in promoting adaptive governance. In the context of emerging adaptive governance systems and the rebalancing of stability and flexibility to manage changing SESs, the relevant laws establish two key elements at the implementation level: substantive requirements and standards, and procedural requirements and opportunities. Notably, moreover, it is often procedural requirements that allow for the flexible administration of otherwise stable governance structures and substantive requirements, but different calibrations of the stability-flexibility balance can be achieved by combining a variety of legal tools and options.

Biber and Eagle (2015) have recently suggested the importance of such calibrations to the success of environmental and natural resources law. They note that the balance of flexibility and stability in the legal regimes for recreational hunting and commercial marine fisheries are similar, but conclude that the exercise of flexibility in each regime produces different management results on the ground: widespread success in hunting regulation compared to considerable failure in marine fisheries regulation.

Adaptive governance in the Anthropocene will, if anything, require increased attention to environmental issues such as pollution (Craig 2010a) and to the management of natural resources such as water, species, and forests (Ruhl 2008, Craig 2010a, Zellmer 2012, Benson and Craig 2014). Therefore, we next examine various tools for balancing and rebalancing stability and flexibility at the level of environmental and natural resources law.

\section{Balancing stability and flexibility in the form of substantive law}

There is a tendency to view substantive law as a set of clear, unchanging, and binding rules. However, processes for changing substantive law almost always exist such as through legislative and administrative amendment. More important for this discussion is the fact that substantive law actually takes a variety of forms, some of which are more inherently flexible than others. Choosing the form of substantive law, therefore, becomes a mechanism for balancing stability and flexibility in environmental and natural resources law.

\section{Inherently evolutionary law}

As several judges and scholars have recognized, "The strength and genius of the common law lies in its ability to adapt to the changing needs of the society it governs" (Brooks v. Robinson, 284 N.E.2d 794, 797 [Ind. 1972]). "Common law" refers to aspects of law such as torts, property, and contract law that have evolved through the collection of rules and principles that judges have announced, often over centuries, in the course of deciding particular cases (Flatt 2012). Although individual states can remove some aspects of these legal subjects from common-law evolution by committing them to statute (e.g., water allocation law, particularly in the western United States but increasingly in the east as well), state legislatures' failures to intervene leaves many areas of law still dominated by judicial decisions that can, over time, reflect the changing norms of society. Principles of precedent (stare decisis) and due process, as well as appeals procedures that allow higher courts to review trial judges' decisions, do constrain judicial inclinations to change commonlaw rules on a regular basis, once again balancing flexibility with a degree of stability. Nevertheless, judges have definitely used particular cases to change state law to reflect new realities, often earning the label of activist in the process. As one example, the Colorado Supreme Court eliminated English riparian water rights and institutionalized prior appropriation in Colorado as a common-law response to Colorado's arid climate and limited water resources (Coffin v. Left Hand Ditch Co., 6 Colo. 443 [1882]).

Far more commonly, however, application of the common law balances stability and flexibility by molding rules and principles that are often centuries old (e.g., "no property owner can use his or her property in a way that constitutes a nuisance") to factual situations that could not have existed even decades ago (e.g., how does the nuisance prohibition apply in the context of rooftop solar energy installations or one neighbor's desire to build a wind turbine in a suburban neighborhood?). Leaving whole areas of law to the common law, therefore, allows relatively stable and consistent rules and principles enough flexibility to cope with changing socioeconomic or social-ecological realities (Flatt 2012).

Sometimes the legal rule itself is regarded as inherently evolutionary, i.e., the rule itself will evolve. The Eighth Amendment to the U.S. Constitution, for example, forbids "cruel and unusual" punishment. The U.S. Supreme Court could have 
interpreted this Amendment to allow any punishment that was legal at the time of the Constitution's adoption. However, the Court has long taken a different approach, concluding that the Amendment's prohibition evolves in light of changing social norms (Gregg v. Georgia, 428 U.S. 153, 171 [1976]). Similarly, most states in the United States recognize some version of a public trust doctrine, which preserves waterways and sometimes other natural resources for public use. A number of states have declared their public trust doctrines to be inherently evolutionary, adapting over time to accommodate new social needs for and valuations of those resources (Craig 2010b).

\section{Rules vs. standards}

Not all substantive law actually consists of rules; instead, much substantive law creates standards, which are far more flexible. Thus, the choice between a rule and a standard allows a governance entity to privilege stability (rule) or flexibility (standard). Rules generally are preferable when clarity, precision, ease of enforcement, and equality of application are of primary concern, whereas standards better implement general principles (e.g., "drive safely") over a range of varying conditions and circumstances (Camacho 2015).

Morse (2010) offers examples of regulating car speed to illustrate the difference between rules and standards. A rule would state that the speed limit on a given street is $50 \mathrm{~km} / \mathrm{h}$, and any exceedance of that speed is a legal violation. In contrast, a standard would provide that motorists commit a moving violation when they drive unreasonably fast, taking into account road conditions and traffic patterns. As Morse summarizes, "applying rules is not only more mechanical, subject to perverse results from over- and under-inclusiveness, but also fair and relatively predictable, whereas applying standards allows for case-by-case adjustment and the consideration of special circumstances at the cost of unpredictability and different treatments of indistinguishable fact patterns" (Morse 2010:563). Moreover, rules and standards are best viewed as forming a continuum rather than a dichotomy (Morse 2010, Camacho 2015), allowing the form of substantive law to balance stability and flexibility in a wide variety of different ways.

\section{Legal floors, legal ceilings, and intelligible principles}

Legal regimes can also add flexibility within stability by dividing rule and standard setting from implementation and interpretation, giving different governance entities responsibility for the different phases of implementing law. This is the basic structure that the U.S. Constitution creates: Congress enacts the laws, the Executive Branch implements them, and the courts interpret them. However, the division of implementation authority can also be accomplished through delegation of certain powers from higher level governance entities (e.g., the federal government or Congress) to lower level entities (e.g., states and tribes or federal agencies), allowing the delegated entities flexibility to interpret and implement core substantive principles and requirements established at the higher level.

In federal law, two kinds of delegations are common: Congress can delegate governance authority to federal agencies, or it can delegate governance authority to states. Delegations of governance authority to federal agencies can be quite broad, effectively giving the federal agency considerable flexibility in deciding whether and how to implement Congress's stated goals and policies. Under federal constitutional law, Congress must supply the delegated agency with an "intelligible principle" to follow, but the U.S. Supreme Court has deemed an instruction to the U.S. Environmental Protection Agency (EPA) to set air quality standards at levels "requisite to protect the public health" sufficient to meet this requirement (Whitman v. American Trucking Associations, 531 U.S. 457, 473-74 [2001]). In implementing this principle, the EPA, in turn, has continually strengthened those air quality standards as evolving science has revealed human health impacts at smaller and smaller concentrations of air pollutants. Thus, the intelligible principle gave the EPA, through legal delegation, the flexibility to respond to emerging science.

In contrast, when delegating regulatory authority to states, Congress more commonly makes use of legal floors and ceilings, a strategy that allows it to respect state sovereignty and principles of federalism while still maintaining some degree of control and stability in the implementation of national laws. For example, most of the federal pollution control laws (e.g., Clean Air Act, Clean Water Act) allow states to take over federal permitting programs and the setting of regulatory requirements. Delegated states must comply with minimum federal requirements, but the statutes also explicitly allow states to enact more stringent requirements if they choose. Thus, the federal law provides the floor of pollution control legal requirements, giving states the flexibility better to protect their own resources in response to local needs and politics. Environmental cooperative federalism, therefore, might be viewed as a form of legal panarchy whereby stability at the higher level (federal) constrains flexibility but does not create rigidity in governance at a lower level (states).

Federal ceilings are less common in environmental law but have the opposite effect, preempting state efforts to impose more stringent requirements than federal law mandates. For example, absent a federal waiver, states cannot regulate emissions from motor vehicles more stringently than the EPA does, with the justification that this national unity provides stability for a national-scale auto industry. Thus, Congress's choice between federal floors and federal ceilings is a balancing of flexibility and stability, one that can encourage or effectively kill states' attempts to experiment in environmental governance.

At the state level, perhaps one of the best examples of the dynamic and multilayered mix of stability and flexibility is state delegation of the broad police power (i.e., power to regulate to protect the public health, safety, morals, and welfare) to local governments, such as in the delegation of land-use planning and regulatory authority (Arnold 2007). The police power and state enabling statutes are often standard, like grants of broad authority, subject to a handful of specific legal minimums and maximums, with the goal that local governments will create plans and zoning rules that create stability in the built environment. However, these rules can be and often are changed, can be varied or waived by permit, and reflect local policy choices, whether prodevelopment or proconservation (Arnold 2007). Moreover, the environmentally protective conditions that regulators impose on the development may become either stable through perpetual implementation or flexible through nonenforcement (Rissman 2011, Owley 2015). 
Emergent new forms of governance

The combination of flexibility and stability in legal regimes can also facilitate the emergence of new forms of governance to adapt to social-ecological complexities. For example, hybrid public-private collaborations to govern watersheds have arisen not only in response to the inflexibilities of existing regulatory regimes (e.g., Endangered Species Act, Clean Water Act), but also because the agencies and stakeholders involved have considerable authority and latitude to form new planning and management systems (Arnold 2011). In addition, private governance of common-pool resources emerges to create new rules for resource management that are flexible, yet create stable relationships, enabled by the fact that the legal system both allows for these commons governance systems and will enforce the rules that private actors adopt (Ostrom 1990).

\section{Choosing legal procedures that pace change appropriately to the context}

Legal procedure is an important tool for both constraining flexibility and allowing for legal flexibility that can operate in socially acceptable (fair and legitimate) ways. As discussed, process is often the mechanism through which normally operating restraints on government can be overcome, e.g., the prohibition on searches and seizures, the deprivation of private property. However, the amount of process required to effectuate legal change is also a highly effective mechanism for constraining or expanding flexibility.

There are a number of ways to make the process of effectuating legal change more or less burdensome, and each such choice thus becomes a mechanism for balancing stability and flexibility. In processes dominated by voting, for example, supermajority voting requirements can slow the amount of change that will occur, favoring stability. Approval by multiple decision makers (as is often required to amend constitutions and is required to enact federal law) can quite effectively limit legal changes to those that have widespread support among the relevant constituencies, again favoring stability. Burdens of proof can vary considerably and can dramatically affect the pace of change: Under the Food, Drug, and Cosmetic Act, for example, drug manufacturers have the burden to establish the safety and efficacy of their products, slowing the pace at which new drugs become available to consumers and potentially limiting doctors' flexibility in treating patients. Conversely, it is the EPA's burden under the Toxic Substances Control Act to prove that new commercial chemicals harm human health or the environment, ensuring that most chemical products go to market, although sometimes leading to toxic torts lawsuits years later when the products' dangers become apparent. The formality of evidentiary evaluations and requirements for public participation can also affect the pace of legal change: The Federal Reserve, not bound by formal procedural requirements, can change interest rates much more quickly in response to changing financial conditions than the EPA, subject to notice-and-comment rule-making requirements, can alter air quality standards. Finally, the number and type of assessments (e.g., an environmental impact assessment or a costbenefit analysis) that must be completed before any legal change can occur will affect the governance entity's nimbleness and flexibility in responding to changing conditions.
Arguably, therefore, procedural design is one of the most important mechanisms for balancing stability and flexibility (Cosens 2013). The more procedure that is required to bring about change, the less flexibility that the relevant governance entity is likely to have. However, too much or too little procedural flexibility in the wrong factual situations can lead to, respectively, arbitrariness or rigidity traps. The history of environmental and natural resources law in the United States has repeatedly suggested needs to re-adjust the balances originally drawn such as by limiting the regulatory contexts in which an environmental impact statement under the National Environmental Policy Act (NEPA; 42 U.S.C. § 4332) or formal consultation with the expert agencies for endangered species under the Endangered Species Act (16 U.S.C. $\S 1536[a][2])$ is required or by imposing cost-benefit analysis requirements.

Moreover, procedural design choices can combine with substantive law choices to allow a wide range of stability and flexibility calibrations to reflect the realities of varying governance contexts. The Federal Reserve, for example, is subject to a substantive legal standard (not rule) and very limited procedural requirements to change interest rates, giving it considerable flexibility to react quickly to changing economic conditions (Craig and Ruhl 2014). Nevertheless, this legal favoring of flexibility, at its best, promotes the overall stability of the U.S. economy. The EPA, in contrast, needs considerable time and scientific evidence to change national air quality standards, and then the standards themselves come with extensive implementation periods. These extensive procedural and evidentiary requirements effectively limit how often human health concerns regarding air quality can dictate potentially major economic dislocations.

These last two examples suggest that legal design to balance stability and flexibility should, after accounting for fairness considerations, be commensurate with the rate at which governance itself might need to adapt (faster for interest rates, slower for air quality). However, in many contexts global climate change adds considerable uncertainty to this issue of governance adaptation in the context of SESs. Thus, in the Anthropocene, mechanisms to rebalance stability and flexibility effectively in environmental and natural resources law are themselves necessary adaptations, suggesting that procedures for amendment and the employment of standards deserve increased attention in these areas of law.

\section{CONCLUSION}

Whereas there is growing consensus that governance systems need additional flexibility both to govern complex and changing SESs effectively and to adapt to climate change, basic principles of good governance (including constitutional constraints), recognized realities within political science and legal jurisprudence, and psychological studies all counsel that no one balancing of stability and flexibility will be appropriate for all governance issues. Instead, stability and flexibility must be balanced to reflect the governance problem and the social risks and realities at hand while remembering that flexibility at one scale (e.g., the individual) may actually promote stability at another (e.g., the community). This need to balance and rebalance stability and flexibility provides a central motivation for identifying the legal and other governance 
tools available to create the variety of calibrations required. However, it also provides a motivation to promote governance regimes such as adaptive governance that can themselves accommodate repeated, adaptive calibrations as the relative value of stability and flexibility in particular situations also shifts.

Responses to this article can be read online at: http://www.ecologyandsociety.org/issues/responses. php/8983

\section{Acknowledgments:}

This work was supported by the National Socio-Environmental Synthesis Center (SESYNC) under funding from the National Science Foundation DBI-1052875. The views expressed in this paper are those of the authors and do not represent the views or policies of the U.S. Environmental Protection Agency. The Nebraska Cooperative Fish and Wildlife Research Unit is jointly supported by a cooperative agreement between the U.S. Geological Survey, the Nebraska Game and Parks Commission, the University of Nebraska-Lincoln, the U.S. Fish and Wildlife Service, and the Wildlife Management Institute.

\section{LITERATURE CITED}

Allen, C. D., C. Birkeland, F. S. Chapin III, P. M. Groffman, and G. R. Guntenspergen. 2009. Thresholds of climate change in ecosystems: final report, synthesis and assessment product 4.2. Publications of the U.S. Geological Survey Paper 13. U.S. Geological Survey, Reston, Virginia, USA. [online] URL: http:// digitalcommons.unl.edu/cgi/viewcontent. cgi? article $=1009 \&$ context $=$ usgspubs

Allen, C. R., D. G. Angeler, A. S. Garmestani, L. H. Gunderson, and C. S. Holling. 2014. Panarchy: theory and application. Ecosystems 17(4):578-589. http://dx.doi.org/10.1007/s10021-013-9744-2

Armitage, D. 2007. Governance and the commons in a multi-level world. International Journal of the Commons 2(1):7-32. http://dx. doi.org/10.18352/ijc. 28

Arnold, C. A. 2007. The structure of the land use regulatory system in the United States. Journal of Land Use and Environmental Law 22(2):441-523. [online] URL: http://www.law. fsu.edu/docs/default-source/journals/jluel/previous-issues/volume-22number-2.pdf?sfvrsn $=4$

Arnold, C. A. 2011. Fourth generation environmental law: integrationist and multimodal. William and Mary Environmental Law and Policy Review 35(3):771-884. [online] URL: http:// scholarship.law.wm.edu/wmelpr/vol35/iss $3 / 3$

Arnold, C. A. 2014. Framing watersheds. Pages 271-302 in K. H. Hirokawa, editor. Environmental law and contrasting ideas of nature: a constructivist approach. Cambridge University Press, Cambridge, UK. http://dx.doi.org/10.1017/cbo9781139519762.015

Arnstein, S. R. 1969. A ladder of citizen participation. Journal of the American Institute of Planners 35(4):216-224. http://dx.doi. org/10.1080/01944366908977225
Attari, S. Z., M. Schoen, C. I. Davidson, M. L. DeKay, W. B. de Bruin, R. Dawes, and M. J. Small. 2009. Preferences for change: Do individuals prefer voluntary actions, soft regulations, or hard regulations to decrease fossil fuel consumption? Ecological Economics 68(6):1701-1710. http://dx.doi.org/10.1016/j. ecolecon.2008.10.007

Baumgartner, F. R., and B. D. Jones. 2015. The politics of information: problem definition and the course of public policy in America. University of Chicago Press, Chicago, Illinois, USA. http://dx.doi.org/10.7208/chicago/9780226198262.001.0001

Benson, M. H., and R. K. Craig. 2014. The end of sustainability. Society and Natural Resources 27(7):777-782. http://dx.doi. org/10.1080/08941920.2014.901467

Biber, E., and J. Eagle. 2015. When does legal flexibility work in environmental law? Ecology Law Quarterly 42(4):787-840. [online] URL: http://scholarship.law.berkeley.edu/elq/vol42/ $\underline{\text { iss } 4 / 2 /}$

Birgé, H. E., C. R. Allen, R. K. Craig, A. S. Garmestani, J. A. Hamm, C. Babbitt, K. Nemec, and E. Schlager. 2014. Socialecological resilience and law in the Platte River basin. Idaho Law Review 51(1):229-256. [online] URL: http://www.uidaho.edu/ / media/UIdaho-Responsive/Files/law/law-review/articles/volume-51/51-1birge-hannah-etal.ashx

Bosserman, R. W. 1983. Dynamics of physical and chemical parameters in Okefenokee swamp. Journal of Freshwater Ecology 2(2):129-140. http://dx.doi.org/10.1080/02705060.1983.9664585

Botkin, D. B. 1992. Discordant harmonies: a new ecology for the twenty-first century. Oxford University Press, Oxford, UK.

Bullard, R. D., and G. S. Johnson. 2000. Environmental justice: grassroots activism and its impact on public policy decision making. Journal of Social Issues 56(3):555-578. http://dx.doi. org/10.1111/0022-4537.00184

Burger, J. M. 1989. Negative reactions to increases in perceived personal control. Journal of Personality and Social Psychology 56 (2):246-256. http://dx.doi.org/10.1037/0022-3514.56.2.246

Camacho, A. E. 2009. Adapting governance to climate change: managing uncertainty through a learning infrastructure. Emory Law Journal 59(1):1-77. [online] URL: http://law.emory.edu/elj/ content/volume-59/issue-1/articles/governance-climate-change-uncertaintyinfrastructure.html

Camacho, A. E. 2011. Transforming the means and ends of natural resources management. North Carolina Law Review 89:1405-1454. http://dx.doi.org/10.2139/ssrn.1852724

Camacho, A. E. 2015. Going the way of the dodo: de-extinction, dualisms, and reframing conservation. Washington University Law Review 92(4):849-906. [online] URL: http://openscholarship. wustl.edu/law lawreview/vo192/iss4/5

Camacho, A. E., and R. L. Glicksman. 2016. Legal adaptive capacity: how program goals and processes shape federal land adaptation to climate change. University of Colorado Law Review 87(3):711-826. [online] URL: http://lawreview.colorado.edu/wpcontent/uploads/2016/01/8.-87.3-Camacho-Glicksman_Final-Revised. pdf 
Carpenter, S. R., and W. A. Brock. 2008. Adaptive capacity and traps. Ecology and Society 13(2):40. http://dx.doi.org/10.5751/ es-02716-130240

Castro, P. 2012. Legal innovation for social change: exploring change and resistance to different types of sustainability laws. Political Psychology 33(1):105-121. http://dx.doi.org/10.1111/ j.1467-9221.2011.00863.x

Castro, P., and C. Mouro. 2011. Psycho-social processes in dealing with legal innovation in the community: insights from biodiversity conservation. American Journal of Community Psychology 47 (3-4):362-373. http://dx.doi.org/10.1007/s10464-010-9391-0

Chaffin, B. C., R. K. Craig, and H. Gosnell. 2014a. Resilience, adaptation, and transformation in the Klamath River basin socioecological system. Idaho Law Review 51(1):157-193. [online] URL: http://www.uidaho.edu/ /media/UIdaho-Responsive/Files/ law/law-review/articles/volume-51/51-1-chaffin-brian-c-etal.ashx

Chaffin, B. C., H. Gosnell, and B. A. Cosens. 2014b. A decade of adaptive governance scholarship: synthesis and future directions. Ecology and Society 19(3):56. http://dx.doi.org/10.5751/ ES-06824-190356

Chaffin, B., L. Gunderson, and B. Cosens, editors. 2017. Practicing panarchy: assessing legal flexibility, ecological resilience, and adaptive governance in U.S. regional water systems experiencing climate change. Ecology and Society SF122. [online] URL: http://www.ecologyandsociety.org/issues/view.php?sf=122

Cornforth, A. 2009. Behaviour change: insights for environmental policy making from social psychology and behavioural economics. Policy Quarterly 5(4):21-28.

Cosens, B. A. 2010. Transboundary river governance in the face of uncertainty: resilience theory and the Columbia River Treaty. Journal of Land, Resources, and Environmental Law 30 (2):229-265. [online] URL: http://epubs.utah.edu/index.php/jlrel/ article/viewArticle/333

Cosens, B. A. 2012. Resilience and law as a theoretical backdrop for natural resource management: flood management in the Columbia River basin. Environmental Law 42(1):241-264.

Cosens, B. A. 2013. Legitimacy, adaptation, and resilience in ecosystem management. Ecology and Society 18(1):3. http://dx. doi.org/10.5751/ES-05093-180103

Cosens, B. A., R. K. Craig, S. Hirsch, C. A. (T.) Arnold, M. H. Benson, D. A. DeCaro, A. S. Garmestani, H. Gosnell, J. Ruhl, and E. Schlager. 2017. The role of law in adaptive governance. Ecology and Society 22(1):30. https://doi.org/10.5751/ES-08731-220130

Cosens, B. A., and A. Fremier. 2014. Assessing system resilience and ecosystem services in large river basins: a case study of the Columbia River basin. Idaho Law Review 51(1):91-125. [online] URL: http://www.uidaho.edu/ /media/UIdaho-Responsive/Files/ law/law-review/articles/volume-51/51-1-cosens-barbara-etal.ashx

Cosens, B. A., and M. K. Williams. 2012. Resilience and water governance: adaptive governance in the Columbia River basin. Ecology and Society 17(4):3. http://dx.doi.org/10.5751/ES-04986-170403

Craig, R. K. 2010a. "Stationarity is dead" — long live transformation: five principles for climate change adaptation law.
Harvard Environmental Law Review 34(1):9-73. [online] URL: http://www.law.harvard.edu/students/orgs/elr/vol34_1/9-74.pdf

Craig, R. K. 2010b. A comparative guide to the western states' public trust doctrines: public values, private rights, and the evolution toward an ecological public trust. Ecology Law Quarterly 37(1):53-197. [online] URL: http://scholarship.law. berkeley.edu/elq/vol37/iss $1 / 2$

Craig, R. K. 2015. Dealing with ocean acidification: the problem, the Clean Water Act, and state and regional approaches. Washington Law Review 90:1583-1657.

Craig, R. K., and M. H. Benson. 2013. Replacing sustainability. Akron Law Review 46(4):841-880. [online] URL: http:// ideaexchange.uakron.edu/akronlawreview/vol46/iss4/2

Craig, R. K., and J. B. Ruhl. 2014. Designing administrative law for adaptive management. Vanderbilt Law Review 67:1-86. http:// dx.doi.org/10.2139/ssrn.2222009

DeCaro, D. A., C. A. (T.) Arnold, E. F. Boamah, and A. S. Garmestani. 2017. Understanding and applying principles of social cognition and decision making in adaptive environmental governance. Ecology and Society 22(1):33. https://doi. org/10.5751/ES-09154-220133

DeCaro, D. A., M. A. Janssen, and A. Lee. 2015. Synergistic effects of voting and enforcement on internalized motivation to cooperate in a resource dilemma. Judgment and Decision Making 10(6):511-537. [online] URL: http://journal.sjdm.org/15/15529/ jdm15529.pdf

DeCaro, D. A., and M. K. Stokes. 2008. Social-psychological principles of community-based conservation and conservancy motivation: attaining goals within an autonomy-supportive environment. Conservation Biology 22(6):1443-1451. http://dx. doi.org/10.1111/j.1523-1739.2008.00996.x

DeCaro, D. A., and M. K. Stokes. 2013. Public participation and institutional fit: a social-psychological perspective. Ecology and Society 18(4):40. http://dx.doi.org/10.5751/ES-05837-180440

Doremus, H. 2010. Adapting to climate change with law that bends without breaking. San Diego Journal of Climate and Energy Law 2:45-85.

Dotan, Y. 2005. Making consistency consistent. Administrative Law Review 57(4):995-1069. [online] URL: http://www.jstor.org/ stable/40712037

Esty, D. C. 2006. Good governance at the supranational scale: globalizing administrative law. Yale Law Journal 115 (7):1490-1562. http://dx.doi.org/10.2307/20455663

Filippov, M., P. C. Ordeshook, and O. Shvetsova. 2004. Designing federalism: a theory of self-sustainable federal institutions. Cambridge University Press, Cambridge, UK. http://dx.doi. org/10.1017/cbo9780511610875

Flatt, V. B. 2012. Adapting laws for a changing world: a systemic approach to climate change adaptation. Florida Law Review 64 (1):269-293.

Frey, B. S., M. Benz, and A. Stutzer. 2004. Introducing procedural utility: not only what, but also how matters. Journal of 
Institutional and Theoretical Economics 160(3):377-401. https:// doi.org/10.1628/0932456041960560

Garmestani, A. S., and C. R. Allen, editors. 2014. Socialecological resilience and law. Columbia University Press, New York, New York, USA. http://dx.doi.org/10.7312/garm16058

Garmestani, A. S., C. R. Allen, and M. H. Benson. 2013. Can law foster social-ecological resilience? Ecology and Society 18(2):37. http://dx.doi.org/10.5751/ES-05927-180237

Garmestani, A. S., and M. H. Benson. 2013. A framework for resilience-based governance of social-ecological systems. Ecology and Society 18(1):9. http://dx.doi.org/10.5751/es-05180-180109

Garrick, D. E., E. Schlager, and S. Villamayor-Tomas. 2016. Governing an international transboundary river: opportunism, safeguards, and drought adaptation in the Rio Grande. Publius: the Journal of Federalism 46(2):170-198. https://doi.org/10.1093/ publius/pjw002

Gibson, J. L., G. A. Caldeira, and V. A. Baird. 1998. On the legitimacy of national high courts. American Political Science Review 92(2):343-358. http://dx.doi.org/10.2307/2585668

Gifford, R., and L. A. Comeau. 2011. Message framing influences perceived climate change competence, engagement, and behavioral intentions. Global Environmental Change 21 (4):1301-1307. http://dx.doi.org/10.1016/j.gloenvcha.2011.06.004

Green, O. O., A. S. Garmestani, C. R. Allen, L. H. Gunderson, J. B. Ruhl, C. A. Arnold, N. A. J. Graham, B. Cosens, D. G. Angeler, B. C. Chaffin, and C. S. Holling. 2015. Barriers and bridges to the integration of social-ecological resilience and law. Frontiers in Ecology and the Environment 13(6):332-337. http://dx. doi.org/10.1890/140294

Gunderson, L., and C. S. Holling, editors. 2002. Panarchy: understanding transformations in human and natural systems. Island Press, Washington, D.C., USA.

Hall, G. E. 2002. High and dry: the Texas-New Mexico struggle for the Pecos River. University of New Mexico Press, Albuquerque, New Mexico, USA.

Hanlon, J. W. 2015. Maintaining robust resource governance: mechanisms of formal institutional change in a federal bargain. Dissertation, School of Government and Public Policy, University of Arizona, Tucson, Arizona, USA. [online] URL: http://hdl.handle.net/10150/577203

Hardin, G. 1968. The tragedy of the commons. Science 162:1243-1248. http://dx.doi.org/10.1126/science.162.3859.1243

Holling, C. S. 1973. Resilience and the stability of ecological systems. Annual Review of Ecology and Systematics 4:1-23. http:// dx.doi.org/10.1146/annurev.es.04.110173.000245

Holling, C. S. 1992. Cross-scale morphology, geometry, and dynamics of ecosystems. Ecological Monographs 62(4):447-502. http://dx.doi.org/10.2307/2937313

Holling, C. S. 2001. Understanding the complexity of economic, ecological, and social systems. Ecosystems 4(5):390-405. http:// dx.doi.org/10.1007/s10021-001-0101-5
Holling, C. S., L. H. Gunderson, and G. D. Peterson. 2002. Sustainability and panarchies. Pages 63-102 in L. H. Gunderson and C. S. Holling, editors. Panarchy: understanding transformations in human and natural systems. Island Press, Washington, D.C., USA.

Holling, C. S., and G. K. Meffe. 1996. Command and control and the pathology of natural resource management. Conservation Biology 10(2):328-337. http://dx.doi.org/10.1046/

j.1523-1739.1996.10020328.x

Intergovernmental Panel on Climate Change (IPCC). 2014. Climate change 2014: synthesis report. Contribution of Working Groups I, II and III to the Fifth Assessment Report of the Intergovernmental Panel on Climate Change [Core Writing Team, R. K. Pachauri, and L. A. Meyer, editors]. IPCC, Geneva, Switzerland. [online] ULR: http://www.ipcc.ch/report/ar5/syr/

Lafon, N. W., S. L. McMullin, D. E. Steffen, and R. S. Schulman. 2004. Improving stakeholder knowledge and agency image through collaborative planning. Wildlife Society Bulletin 32 (1):220-231. http://dx.doi.org/10.2193/0091-7648(2004)32[220: iskaai]2.0.co;2

Lavergne, K. J., E. C. Sharp, L. G. Pelletier, and A. Holtby. 2010. The role of perceived government style in the facilitation of selfdetermined and non self-determined motivation for proenvironmental behavior. Journal of Environmental Psychology 30 (2):169-177. http://dx.doi.org/10.1016/j.jenvp.2009.11.002

Lawrence, R. L., S. E. Daniels, and G. H. Stankey. 1997. Procedural justice and public involvement in natural resource decision making. Society and Natural Resources 10(6):577-589. http://dx.doi.org/10.1080/08941929709381054

Leach, W. D., and P. A. Sabatier. 2005. To trust an adversary: integrating rational and psychological models of collaborative policymaking. American Political Science Review 99(4):491-503. http://dx.doi.org/10.1017/s000305540505183x

Levi-Faur, D., editor. 2012. The Oxford handbook of governance. Oxford University Press, Oxford, UK. http://dx.doi.org/10.1093/ oxfordhb/9780199560530.001.0001

Levin, S. A. 1992. The problem of pattern and scale in ecology: the Robert H. MacArthur Award lecture. Ecology 73 (6):1943-1967. http://dx.doi.org/10.2307/1941447

McComas, K. A., R. Stedman, and P. S. Hart. 2011. Community support for campus approaches to sustainable energy use: the role of "town-gown" relationships. Energy Policy 39(5):2310-2318. http://dx.doi.org/10.1016/j.enpol.2011.01.045

Milly, P. C. D., J. Betancourt, M. Falkenmark, R. M. Hirsch, Z. W. Kundzewicz, D. P. Lettenmaier, and R. J. Stouffer. 2008. Stationarity is dead: whither water management? Science 319:573-574. http://dx.doi.org/10.1126/science.1151915

Mitchell, M. 2009. Complexity: a guided tour. Oxford University Press, Oxford, UK.

Moller, A. C., R. M. Ryan, and E. L. Deci. 2006. Selfdetermination theory and public policy: improving the quality of consumer decisions without using coercion. Journal of Public Policy and Marketing 25(1):104-116. http://dx.doi.org/10.1509/ jppm.25.1.104 
Morse, A. H. 2010. Rules, standards, and fractured courts. Oklahoma City University Law Review 35:559-605.

Moser, S. C., and J. A. Ekstrom. 2010. A framework to diagnose barriers to climate change adaptation. Proceedings of the National Academy of Sciences 107(51):22026-22031. http://dx.doi. org/10.1073/pnas.1007887107

National Civic League (NCL). 2013. Making public participation legal. NCL, Denver, Colorado, USA. [online] URL: http://ncdd. org/rc/wp-content/uploads/MakingP2Legal.pdf

New York Department of State. 1997. New York City watershed Memorandum of Agreement. Department of State Watershed Protection and Partnership Council, Peekskill, New York, USA. [online] URL: http://www.dos.ny.gov/watershed/nycmoa.html

Ostrom, E. 1990. Governing the commons: the evolution of institutions for collective action. Cambridge University Press, Cambridge, UK.

Ostrom, E. 1998. A behavioral approach to the rational choice theory of collective action: presidential address, American Political Science Association, 1997. American Political Science Review 92(1):1-22. [online] URL: http://www.jstor.org/stable/2585925

Ostrom, E. 2007. A diagnostic approach for going beyond panaceas. Proceedings of the National Academy of Sciences 104:15181-15187. http://dx.doi.org/10.1073/pnas.0702288104

Ostrom, E. 2010. Beyond markets and states: polycentric governance of complex economic systems. American Economic Review 100(3):641-672. http://dx.doi.org/10.1257/aer.100.3.641

Owley, J. 2015. Keeping track of conservation. Ecology Law Quarterly 42(1):79-138. [online] URL: http://scholarship.law. berkeley.edu/elq/vol42/iss $1 / 3$

Parks, C. D., J. Joireman, and P. A. M. Van Lange. 2013. Cooperation, trust, and antagonism: how public goods are promoted. Psychological Science in the Public Interest 14 (3):119-165. http://dx.doi.org/10.1177/1529100612474436

Peterson, G., C. R. Allen, and C. S. Holling. 1998. Ecological resilience, biodiversity, and scale. Ecosystems 1(1):6-18. http://dx. doi.org/10.1007/s100219900002

Porter, E. 2015. Imagining a world without growth. The New York Times December 1. [online] URL: http://www.nytimes. com/2015/12/02/business/economy/imagining-a-world-without-growth. $\underline{\text { html?emc}=\text { eta } 1}$

Rabin, E. H. 1984. Revolution in residential landlord-tenant law: causes and consequences. Cornell Law Review 69(3):517-584. [online] URL: http://scholarship.law.cornell.edu/clr/vol69/iss3/2/

Reed, M. S. 2008. Stakeholder participation for environmental management: a literature review. Biological Conservation 141 (10):2417-2431. http://dx.doi.org/10.1016/j.biocon.2008.07.014

Rissman, A. R. 2011. Evaluating conservation effectiveness and adaptation in dynamic landscapes. Law and Contemporary Problems 74(4):145-173. [online] URL: http://scholarship.law. duke.edu/lcp/vol74/iss4/7

Ruhl, J. B. 2008. Climate change and the Endangered Species Act: building bridges to the no-analog future. Boston University Law
Review 88(1):1-62. [online] URL: http://www.bu.edu/law/ journals-archive/bulr/documents/ruhl.pdf

Ruhl, J. B. 2011. General design principles for resilience and adaptive capacity in legal systems - with applications to climate change adaptation. North Carolina Law Review 89(5):1373-1403. [online] URL: http://scholarship.law.unc.edu/cgi/viewcontent. cgi? article $=4506 \&$ context $=$ nclr

Ruhl, J. B., and R. L. Fischman. 2010. Adaptive management in the courts. Minnesota Law Review 95(2):424-484. [online] URL: http://www.minnesotalawreview.org/articles/adaptive-managementin-the-courts/

Ryan, R. M., and E. L. Deci. 2006. Self-regulation and the problem of human autonomy. Journal of Personality 74 (6):1557-1585. http://dx.doi.org/10.1111/j.1467-6494.2006.00420. $\underline{x}$

Scheffer, M., S. Carpenter, J. A. Foley, C. Folke, and B. H. Walker. 2001. Catastrophic shifts in ecosystems. Nature 413:591-596. http://dx.doi.org/10.1038/35098000

Schlager, E. and W. Blomquist. 2008. Embracing watershed politics. University Press of Colorado, Boulder, Colorado, USA.

Schlager, E., and T. Heikkila. 2009. Resolving water conflicts: a comparative analysis of interstate river compacts. Policy Studies Journal 37(3):367-392. http://dx.doi.org/10.1111/j.1541-0072.2009.00319. $\underline{x}$

Sprankling, J. G., and R. R. Coletta. 2012. Property: a contemporary approach. Second edition. West Publishing, St. Paul, Minnesota, USA.

Steffen, W., K. Richardson, J. Rockström, S. E. Cornell, I. Fetzer, E. M. Bennett, R. Biggs, S. R. Carpenter, W. de Vries, C. A. de Wit, C. Folke, D. Gerten, J. Heinke, G. M. Mace, L. M. Persson, V. Ramanathan, B. Reyers, and S. Sörlin. 2015. Planetary boundaries: guiding human development on a changing planet. Science 347:1259855. http://dx.doi.org/10.1126/science.1259855

Sullivan, S. 1996. Guest editorial: towards a non-equilibrium ecology: perspectives from an arid land. Journal of Biogeography 23(1):1-5. http://www.jstor.org/stable/2846012

Swim, J., S. Clayton, T. Doherty, R. Gifford, G. Howard, J. Reser, P. Stern, and E. Weber. 2009. Psychology and global climate change: addressing a multi-faceted phenomenon and set of challenges. Report of the American Psychological Association Task Force on the Interface between Psychology and Global Climate Change. American Psychological Association, Washington, D.C., USA. [online] URL: http://www.apa.org/ science/about/publications/climate-change.aspx

Turner, R. A., C. Fitzsimmons, J. Forster, R. Mahon, A. Peterson, and S. M. Stead. 2014. Measuring good governance for complex ecosystems: perceptions of coral reef-dependent communities in the Caribbean. Global Environmental Change 29:105-117. http:// dx.doi.org/10.1016/j.gloenvcha.2014.08.004

Tyler, T. R. 1990. Why people obey the law. Yale University Press, New Haven, Connecticut, USA.

Tyler, T. R. 1998. What is procedural justice?: Criteria used by citizens to assess the fairness of legal procedures. Law and Society Review 22(1):103-136. http://dx.doi.org/10.2307/3053563 
Tyler, T. R. 2006. Psychological perspectives on legitimacy and legitimation. Annual Review of Psychology 57:375-400. http://dx. doi.org/10.1146/annurev.psych.57.102904.190038

Tyler, T. R., and P. Degoey. 1995. Collective restraint in social dilemmas: procedural justice and social identification effects on support for authorities. Journal of Personality and Social Psychology 69(3):482-497. http://dx.doi.org/10.1037/0022-3514.69.3.482

Victor, P. A. 2012. Growth, degrowth and climate change: a scenario analysis. Ecological Economics 84:206-212. http://dx.doi. org/10.1016/j.ecolecon.2011.04.013

Walker, B. H., and D. Salt. 2006. Resilience thinking: sustaining ecosystems and people in a changing world. Island Press, Washington, D.C., USA.

Zellmer, S. 2012. Wilderness, water, and climate change. Environmental Law 42:313-374. [online] URL: http:// digitalcommons.unl.edu/lawfacpub/183/

Zellmer, S., and L. Gunderson. 2009. Why resilience may not always be a good thing: lessons in ecosystem restoration from Glen Canyon and the Everglades. Nebraska Law Review 87 (4):893-949. [online] URL: http://digitalcommons.unl.edu/cgi/ viewcontent .cgi? article $=1045 \&$ context $=$ nlr 